\title{
Antimicrobial and Anticancer Activity Studies on Green Synthesized Silver Oxide Nanoparticles from the Medicinal Plant Cyathea nilgiriensis Holttum
}

\author{
Ganeshan Pradheesh ${ }^{1 *}$, Santhanam Suresh ${ }^{2}$, Joghee Suresh ${ }^{3}$, Vincent Alexramani ${ }^{4}$ \\ 'Department of Chemistry, SNS College of Technology, Coimbatore - 641035, Tamil Nadu, INDIA. \\ ${ }^{2}$ Department of Chemistry, National College, Trichy-620002, Tamil Nadu, INDIA. \\ ${ }^{3}$ Department of Chemistry, Sri Ramakrishna Engineering College, Coimbatore - 641022, Tamil Nadu, INDIA. \\ ${ }^{4}$ Department of Chemistry, St. Joseph' College, Trichy - 620002, Tamil Nadu, INDIA.
}

\begin{abstract}
Objectives: To synthesize silver oxide nanoparticles from the medicinal plant Cyathea nilgiriensis Holttum and to evaluate the percentage of inhibition of silver oxide nanoparticles against some selective bacterial species (three gram positive and three gram negative) and two fungal species. Anticancer activity was performed for $\mathrm{Ag}_{2} \mathrm{O}$ nanoparticles using Trypan Blue Assay Method using Daltons lymphoma ascites cells. Methods: Silver oxide nanoparticles were synthesized by chemical precipitation method using the extract of the medicinal plant Cyathea nilgiriensis Holttum and Silver nitrate. Particle size Analyzer (PSA), X-ray Diffraction Analysis (XRD), Fourier Transform Infrared Spectroscopy (FT-IR), Scanning Electron Microscope Analysis (SEM) and Energy Dispersive X-Ray (EDX) studies studies were employed to confirm the size distribution, composition and crystallographic structure of the Silver oxide nanoparticles. Results: Particle size Analyzer and X-ray diffraction results proved the size and crystalline nature of $\mathrm{Ag}_{2} \mathrm{O}$ nanoparticles. Fourier transform infrared spectroscopy studies has proved that biomolecules has acted as chapping and stabilizing agents in the synthesis of $\mathrm{Ag}_{2} \mathrm{O}$ nanoparticle, Scanning electron microscope analysis has exhibited morphological appearance of $\mathrm{Ag}_{2} \mathrm{O}$ nanoparticles and Energy Dispersive $\mathrm{X}$-Ray analysis has proved the presence of both silver and oxygen in the synthesized $\mathrm{Ag}_{2} \mathrm{O}$ nanoparticles. On comparing the zone of
\end{abstract}

inhibition of three-gram positive bacterial species, M. luteus $(20 \mathrm{~mm})$ has shown larger zone of inhibition $(20 \mathrm{~mm})$ and when comparing the zone of inhibition of three-gram negative bacterial species, $K$. pneumoniae has shown larger zone of inhibition $(21 \mathrm{~mm})$. The increase of concentration from $10 \mu \mathrm{g}$ to $200 \mu \mathrm{g}$ of $\mathrm{Ag}_{2} \mathrm{O}$ nanoparticles increases the anticancer efficiency of the biosynthesized $\mathrm{Ag}_{2} \mathrm{O}$ nanoparticles. Conclusion: The Instrumentation results have proved the characteristic nature of the synthesized $\mathrm{Ag}_{2} \mathrm{O}$ nanoparticles. Now it's clear that greener synthesized nanoparticles has proved to be better antimicrobial and anticancer agents. Key words: Cyathea nilgiriensis Holttum, $\mathrm{Ag}_{2} \mathrm{O}$ nanoparticles, Green chemistry, Characterization, antimicrobial and anticancer activity.

Correspondence

Pradheesh G,

Department of Chemistry, SNS College of Technology, Coimbatore-641035, Tamil Nadu, INDIA

Phone: +919047637329

Email: pradheeshchem@gmail.com;

ORCID: http://orcid.org/0000-0002-3729-5303

DOI: 10.5530/ijpi.2020.2.27

\section{INTRODUCTION}

Metallic Nano particles obtained using plant extract could be reducing and capping agents. ${ }^{1,2}$ Due to the unique properties silver oxide nanoparticle it is used in the fields such as sensing, optoelectronic, drug delivery, ${ }^{3,4}$ oxidation catalysis, ${ }^{5,6}$ sensors, ${ }^{7}$ fuel cells, ${ }^{8}$ photovoltaic cells, ${ }^{9}$ all-optical switching devices, optical data storage system $\mathrm{s}^{10}$ and in diagnostic biological probes. ${ }^{11}$ The syntheses of nanoparticles through chemical methods are expensive, time consuming and are not ecofriendly. Hence, Greener methods of synthesis of $\mathrm{Ag}_{2} \mathrm{O}$ nanoparticles have attracted many researchers wing to their cost-effectiveness and non-toxic nature. ${ }^{12-14}$ The green synthesis techniques make use of nontoxic solvents such as water, biological extract, biological systems and microwave irradiation. The use of plant leaf extracts, bacteria, fungi and enzymes for the synthesis of silver nanoparticles offer numerous benefits of eco-friendliness and compatibility for pharmaceutical and other biomedical applications. Green synthesis does not require high pressure, energy, temperature and toxic chemicals. Silver has been recognized to have inhibitory effect on microbes present in medical and industrial process. The topical ointments having silver and silver nanoparticles are medicinally useful to prevent infections against burns and open wounds. ${ }^{15}$ Thus synthesis of nanoparticles by greener methods gain importance. In the present study, the medicinal plant Cyathea nilgiriensis plant extract has been used to produce silver oxide nanoparticles. Based on the literature survey it is evident that the systematic study on the bio-synthesis and characterization of $\mathrm{Ag}_{2} \mathrm{O}$ nanoparticles using Cyathea nilgiriensis Holttum extract has been carried out for the first time.

\section{MATERIALS AND METHODS}

\section{Plant materials collection and preparation}

The pure and analar-grade Silver nitrate $\left[\mathrm{AgNO}_{3}\right]$ was used for this study. The pure and shade-dried leaves of Cyathea nilgiriensis ( $2 \mathrm{~g}$ ) were powdered and subjected to extraction using deionized water. The extract obtained was filtered through Whatman No. 1 filter paper and stored in a refrigerator for further use.

\section{Synthesis of $\mathrm{Ag}_{2}$ Onanoparticles}

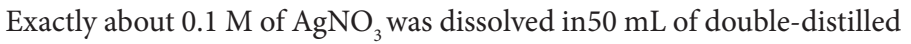
water along with $10 \mathrm{~mL}$ of Cyathea nilgiriensis aqueous extract under under magnetic stirring at $80^{\circ} \mathrm{C}$ for $4 \mathrm{hr}$. The complex formed was ultra-centrifuged at $10,000 \mathrm{rpm}$ for $10 \mathrm{~min}$, rinsed with water and further 
centrifuged at 5,000 $\mathrm{rpm}$ for $10 \mathrm{~min}$. The complex residue was dried in an oven at $40^{\circ} \mathrm{C}$ for $8 \mathrm{~h}$ and was then calcined in a muffle furnace at $600^{\circ} \mathrm{C}$ to obtain biosynthesized $\mathrm{Ag}_{2} \mathrm{O}$ nanoparticles.

\section{Instrumentation for Characterization of Nanomaterial}

The size of the nanoparticle was measured using the particle size analyzer (Nanophox, Sympatec, Germany). The biosynthesized $\mathrm{Ag}_{2} \mathrm{O}$ nanoparticles were analyzed for IR characteristics using a Nicolet 520P FT-IR spectrometer set to be in the range of $500-4,000 \mathrm{~cm}^{-1}$. A powder XRD analysis was carried out on a PAN analytical X-ray diffractometer operated at $40 \mathrm{kV}$ with a current of $30 \mathrm{~mA}$ under $\mathrm{Cu}-\mathrm{Ka}$ radiation of a $2 \theta$ range of $10-80^{\circ}$.The SEM images were recorded using a JEOL JSM 6390 system to identify the crystallographic details of $\mathrm{Ag}_{2} \mathrm{O}$ nanoparticles. To confirm the presence of the constituent elements - silver and oxygen, an energy dispersive spectroscopic (JED 2300, JEOL) study was done on $\mathrm{Ag}_{2} \mathrm{O}$ nanoparticles.

\section{Antimicrobial activity}

The antimicrobial activity was studied applying the disc diffusion method. ${ }^{16}$ Ciprofloxacin and fluconazole were taken as standards for antimicrobial activity. A panel of 6 common pathogenic bacteria consisting of three gram-positive type S. aureus (NCIM 2079), B. subtilis (NCIM 2063), M. luteus (MCIM2169) and three-gram negative type E. coli (NCIM 2065), S. paratyphi (NCIM 2501), K. pneumonia (NCIM2707) and 2 fungal strains C. albicans (MTCC 3100) and A. niger (MTCC 1344) was used. These microbial strains were obtained from the Kovai Medical College and Hospital (KMCH), Coimbatore, Tamil Nadu, India.

\section{Anticancer activity}

The in vitro cytotoxicity potentials of the biosynthesized $\mathrm{Ag}_{2} \mathrm{O}$ nanoparticles were evaluated using Trypan blue dye assay method. ${ }^{17,18}$ The cells were aspirated from the peritoneal cavity of tumor bearing mice. The cells were washed three times using PBS and the viability of the cells was checked using trypan blue. Different concentrations (10,20, 50, 100 and $200 \mu \mathrm{g}$ ) of $\mathrm{Ag}_{2} \mathrm{O}$ nanoparticles were prepared. In a test tube, $100 \mu \mathrm{l}$ of $\mathrm{Ag}_{2} \mathrm{O}$ nanoparticles was mixed with $800 \mu$ l of phosphate buffer saline and $100 \mu \mathrm{l}\left(1 \times 10^{6}\right.$ in $\left.1 \mathrm{ml}\right)$ of Dalton's Lymphoma Ascites (DLA) was added. All the test tubes were incubated at $37^{\circ} \mathrm{C}$ for $3 \mathrm{hr}$. About $100 \mu \mathrm{l}$ of trypan blue dye was added to each of the test tubes. Dead cells got stained by the trypan blue color while live cells did not absorb the dye. The numbers of stained and unstained cells were measured using hemocytometer. Percentage of cytotoxicity was calculated by the given formula.

Where

$$
\text { Cytotoxicity }(\%)=\left(\mathrm{N}_{\mathrm{d}} / \mathrm{N}_{\mathrm{d}}+\mathrm{N}_{\mathrm{l}}\right) \times 100
$$

$$
\mathrm{Nd} \text { - No of dead cells }
$$

$$
\mathrm{N}_{1} \text { - No of live cells }
$$

\section{RESULTS}

\section{Particle Size Analyzer}

The average size of the nanoparticles and the statistical distribution of the size were determined using the particle size analyzer. The results are shown in Figure 2. The particle size of silver oxide nanoparticles is found to be below $100 \mathrm{~nm}$.

\section{Fourier Transform Infrared Spectroscopy Analysis}

Figure 3 shows the FT-IR spectrum of bio-synthesized silver oxide nanoparticles. The peak around $574 \mathrm{~cm}^{-1}$ corresponds to $\mathrm{Ag}$-O vibrations. ${ }^{19-21}$ Other bands can be attributed to silver nitrate and the phytochemical constituents of the leaf extract. The $\mathrm{O}-\mathrm{H}$ stretch appears in the spectrum at $3449 \mathrm{~cm}^{-1}$. The band $1629 \mathrm{~cm}^{-1}$ corresponds to the carbonyl group of flavonoids. Strong band at $1383 \mathrm{~cm}^{-1}$ corresponds to phenolic stretching

\section{$\mathrm{AgNO}_{3}$}

Silver Nitrate

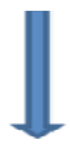

$\mathrm{Ag}^{+}$ions

Ligand of Plant Extract (L)

$\left[\mathrm{Ag}^{+}-\mathrm{L}\right]$ Complex

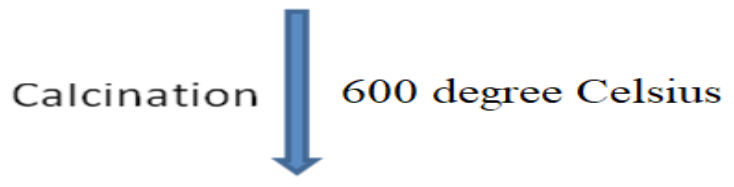

$\mathrm{Ag}_{2} \mathrm{O}$ Nanoparticle

Figure 1: Scheme of $\mathrm{Ag}_{2} \mathrm{O}$ Nanoparticle synthesis.

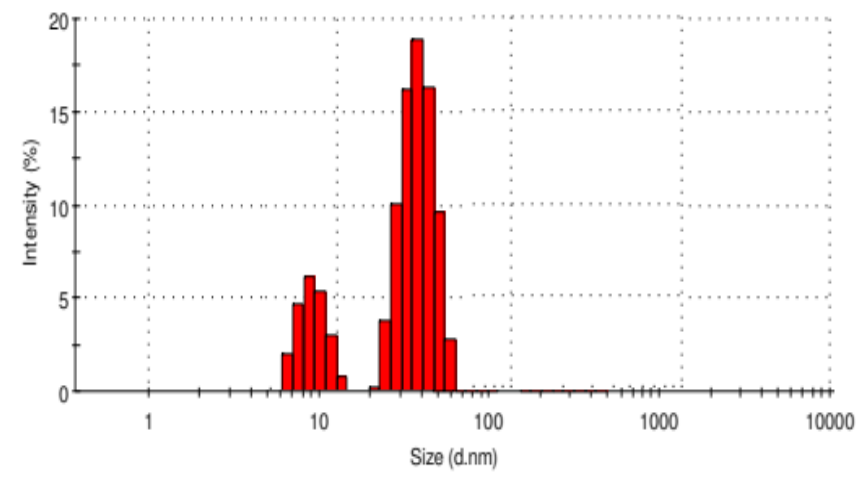

Figure 2: $\mathrm{PSA}$ of $\mathrm{Ag}_{2} \mathrm{O}$ nanoparticle.

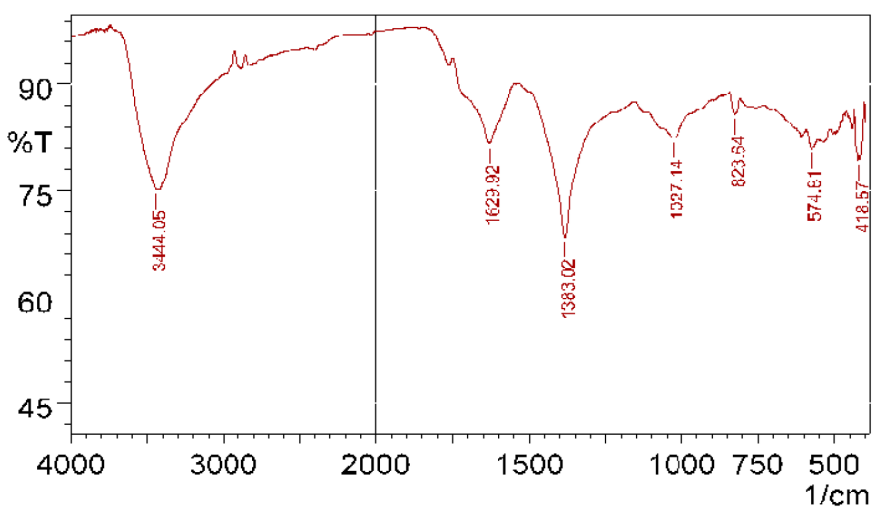

Figure 3: $\mathrm{FT}-\mathrm{IR}$ spectra of $\mathrm{Ag}_{2} \mathrm{O}$ nanoparticles. 


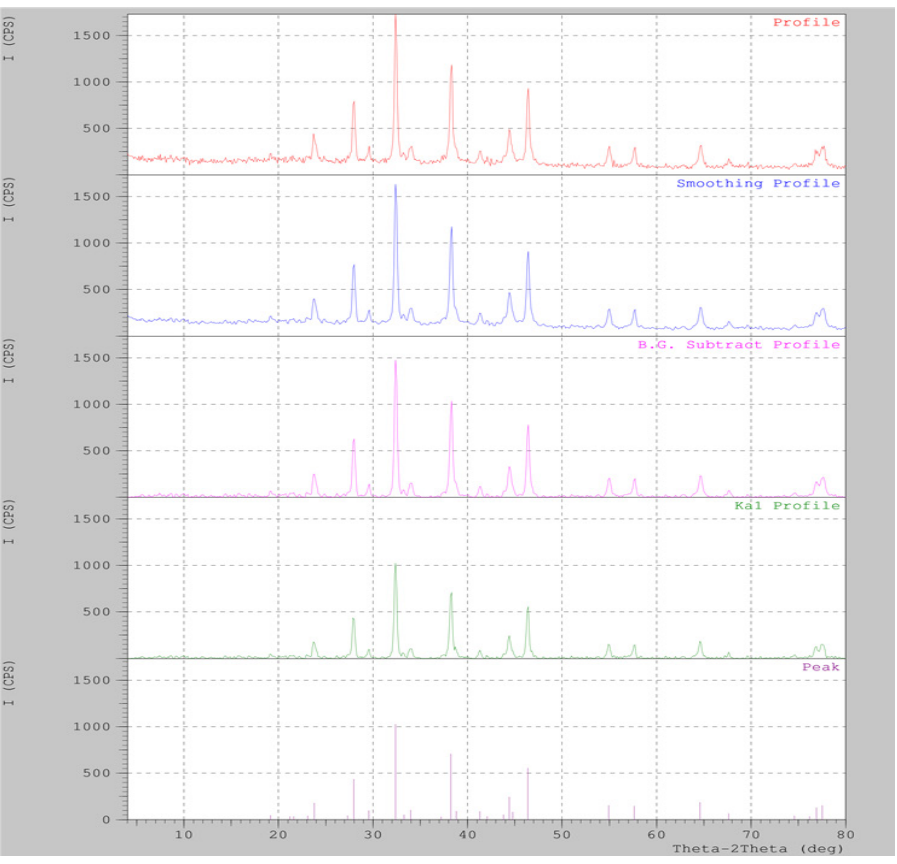

Figure 4: XRD spectra of $\mathrm{Ag}_{2}$ Onanoparticles.

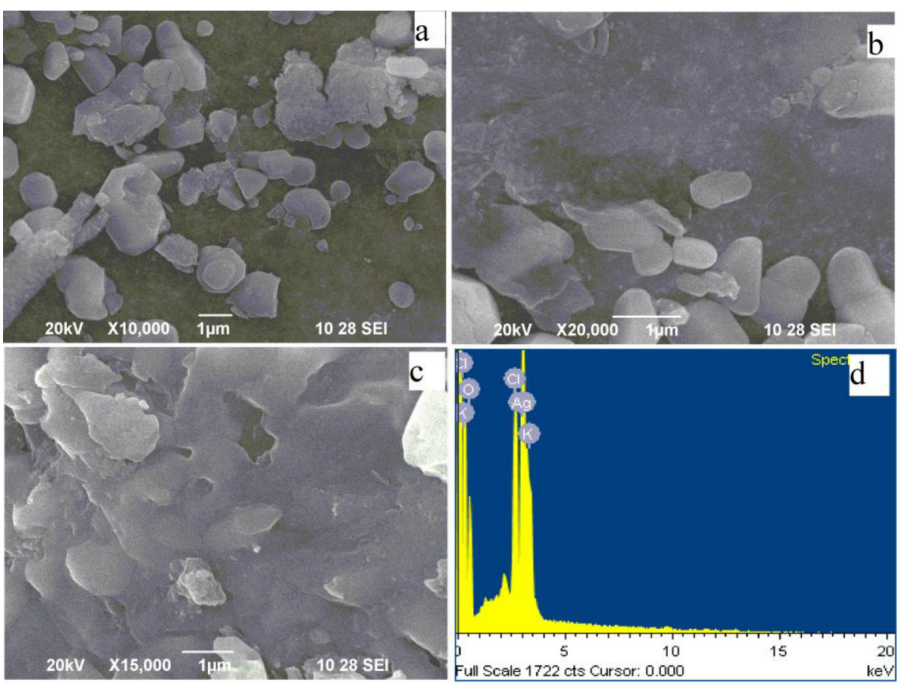

Figure 5: $\operatorname{SEM}(\mathrm{a}, \mathrm{b} \& \mathrm{c})$ \& (d) EDX spectra of $\mathrm{Ag}_{2} \mathrm{O}$ nanoparticles.

vibrations. Strong band at $823 \mathrm{~cm}^{-1}$ corresponds to aromatic C-H bending. The results of FT-IR analysis indicated that phenolic type of compound has favored and stabilized the formation of metal nanoparticles minimizing the agglomeration. Figure 1 shows the scheme of the nanoparticle synthesis.

\section{X-ray diffractometer}

Figure 4 Shows the X-ray diffractometer (XRD) spectrum of the biosynthesized silver oxide nanoparticles. It shows intense band peaks at $27.94,32.27,46.34,54.92$ and 67.48 which corresponds to (110), (111), (211), (220) and (222) planes of face centered cubic silver respectively. All the obtained peaks are similar to standard pure $\mathrm{Ag}_{2} \mathrm{O}^{22,23}$ The average size of the particles was determined by applying the Debye-Scherrer's formula.

\section{Morphological analysis}

The SEM and EDX images of synthesized silver oxide nanoparticles are shown in Figure 5 (a), (b), (c) and (d). The results showed that $\mathrm{Ag}_{2} \mathrm{O}$ nanoparticles were formed in different sizes and below $100 \mathrm{~nm}$. A closer look at the image shows the presence of several nanoparticle clusters. In Figure 5 (a), particles the particles appear to be agglomerated and some individual crystals are clearly visible and are hexagonal in shape. In Figure 5 (b) and (c) some particles appear to be spherical in shape. The EDX results shown in Figure 5(d) further confirm the presence of silver and oxygen.

\section{Antimicrobial activity of $\mathrm{Ag}_{2} \mathrm{O}$ nanoparticles}

In this study antimicrobial activity of $\mathrm{Ag}_{2} \mathrm{O}$ nanoparticles synthesized using the extract of the medicinal plant Cyathea nilgiriensis was found to be significant. Figure 6 shows the antibacterial activity of the biosynthesized $\mathrm{Ag}_{2} \mathrm{O}$ nanoparticles. Antibacterial activity was measured against three grams of positive bacteria ( $S$. aureus, B. subtilis, M. luteus) and three gram of negative bacteria (E. coli, S. paratyphi, K. pneumoniae). Anti-fungal activity was carried out against $C$. albicans and A. niger, Ciprofloxacin is taken as the standard for all microbial strains. Table 1 . Shows inhibitory effect of the $\mathrm{Ag}_{2} \mathrm{O}$ nanoparticles. The zone of inhibition for standard ciprofloxacin for three gram positive bacteria was found to be $34 \mathrm{~mm}$ (S. aureus), $27 \mathrm{~mm}$ (B. subtilis) and $36 \mathrm{~mm} \mathrm{M}$. luteus. The zones of inhibition of $\mathrm{Ag}_{2} \mathrm{O}$ nanoparticles for three gram positive bacteria are found to be $14 \mathrm{~mm}$ (S. aureus), $12 \mathrm{~mm}$ (B. subtilis) and $20 \mathrm{~mm} \mathrm{M}$. luteus. When we compare the above zone of inhibition of $\mathrm{Ag}_{2} \mathrm{O}$ nanoparticles for three gram positive bacteria, $M$. luteus $(20 \mathrm{~mm})$ shows a larger zone of inhibition. The zone of inhibition of standard ciprofloxacin for three gram negative bacteria ranges from $36 \mathrm{~mm}$ (E coli), $35 \mathrm{~mm}$ (S. paratyphi) and $32 \mathrm{~mm}$ (K. pneumoniae).The zones of inhibition of $\mathrm{Ag}_{2} \mathrm{O}$ nanoparticles for three gram negative bacteria are found to be $15 \mathrm{~mm}$ (E coli), $17 \mathrm{~mm}$ (S. paratyphi) and $21 \mathrm{~mm}$ (K. pneumoniae). On comparing the zone inhibition values of $\mathrm{Ag}_{2} \mathrm{O}$ nanoparticles for three-gram negative bacterial species K. pneumoniae $(21 \mathrm{~mm})$ shows a larger zone of inhibition. Table 2. Shows antifungal results for the biosynthesized $\mathrm{Ag}_{2} \mathrm{O}$ nanoparticles. The antifungal images of the $\mathrm{Ag}_{2} \mathrm{O}$ nanoparticles protecting against two strains are shown in Figure 7. The zone of inhibition for the standard fluconazole of two fungal species was found to be C. albicans $(35 \mathrm{~mm})$ and $A$. niger $(09 \mathrm{~mm})$. The zone of inhibition of $\mathrm{Ag}_{2} \mathrm{O}$ nanoparticles for two fungal species is found to be C. albicans $(13 \mathrm{~mm})$ and A. nige $(10 \mathrm{~mm})$.

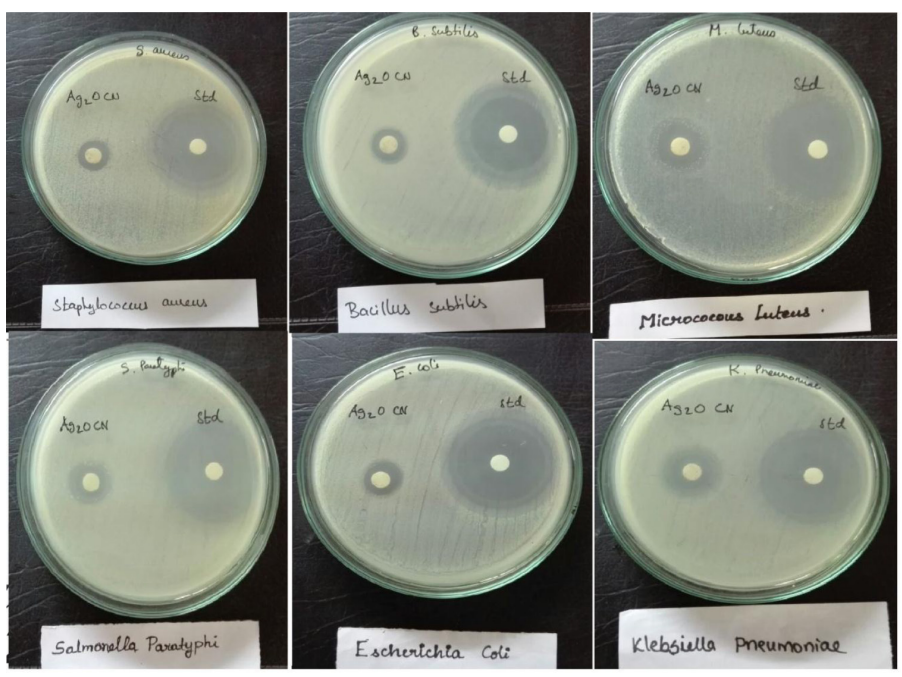

Figure 6: Antibacterial images of $\mathrm{Ag}_{2} \mathrm{O}$ nanoparticles a) $\mathrm{S}$. aureus b) B. subtilis, c) M. luteusd) S. Paratyphi e) E. colif) K. pneumonia 
Table 1: Zone inhibition values of gram positive and gram negative bacterias.

\begin{tabular}{ccc}
\hline \multirow{2}{*}{ Name of organisms } & \multicolumn{2}{c}{ Zone of Inhibition $(\mathrm{mm})$} \\
\cline { 2 - 3 } & $\begin{array}{c}\text { Std } \\
\text { Ciprofloxacin } \\
(10 \mu \mathrm{g} / \mathrm{disc})\end{array}$ & $\begin{array}{c}\text { Samples } \\
(100 \mu \mathrm{g} / \mathrm{disc})\end{array}$ \\
\cline { 3 - 3 } S. aureus & 34 & $\mathrm{CN}-\mathrm{Ag}_{2} \mathrm{O}$ \\
B. subtilis & 27 & 14 \\
M. luteus & 36 & 12 \\
E. coli & 36 & 20 \\
S. paratyphi & 35 & 15 \\
K. pneumoniae & 32 & 17 \\
\hline
\end{tabular}

Table 2: Zone inhibition values of fungal species.

\begin{tabular}{ccc}
\hline \multirow{2}{*}{ Name of organisms } & \multicolumn{2}{c}{ Zone of Inhibition $(\mathrm{mm})$} \\
\cline { 2 - 3 } & $\begin{array}{c}\text { Std } \\
\text { Ciprofloxacin } \\
(10 \mu \mathrm{g} / \mathrm{disc})\end{array}$ & $\begin{array}{c}\text { Samples } \\
(100 \mu \mathrm{g} / \mathrm{disc})\end{array}$ \\
\cline { 2 - 3 } A. niger & 09 & $\mathrm{CN}-\mathrm{Ag}_{2} \mathrm{O}$ \\
C. albicans & 35 & 10 \\
\hline
\end{tabular}

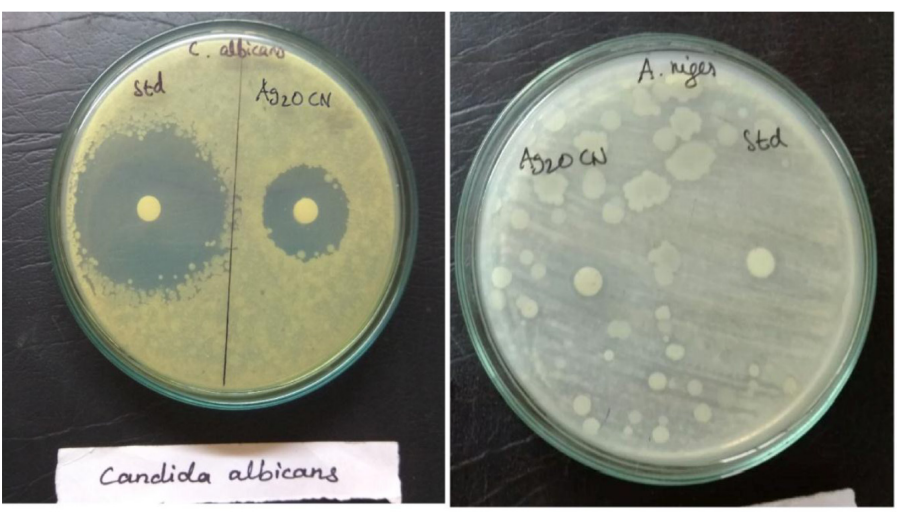

Figure 7: Antifungal images of $\mathrm{Ag}_{2} \mathrm{O}$ nanoparticles a) C.albicans b) A.niger

From the above result it's clear that C.albicans $(13 \mathrm{~mm})$ presents a larger zone of inhibition compared to those of the other fungal species A. niger $(10 \mathrm{~mm})$ for the synthesized $\mathrm{Ag}_{2} \mathrm{O}$ nanoparticles. Thus, nanoparticles can be used as antifungal agents and can help to overcome hurdles of fungal diseases in human beings.

\section{Anticancer activity}

Several in vitro studies have indicated that silver nanoparticles can enter cells by endocytosis. ${ }^{24}$ Figure 8. [a-f] shows anticancer images of $\mathrm{Ag}_{2} \mathrm{O}$ nanoparticles at different concentrations. DLA (Daltons lymphoma ascites) bearing mice cell lines is used for finding cancer activity using

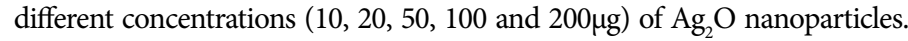
The cyclophosphamide drug is taken as a standard for the DLA cell line. Figure 8a shows a control image which has no inhibition. The cyclophosphamide drug is taken as a standard for the DLA cell line. Figure 8a shows a control image which shows no inhibition. Figure 8 [b-f] shows clear that $\mathrm{Ag}_{2} \mathrm{O}$ nanoparticles have increasing percentage of inhibition over higher concentration of the test sample. Table 3 shows the anticancer activity of $\mathrm{Ag}_{2} \mathrm{O}$ nanoparticles.
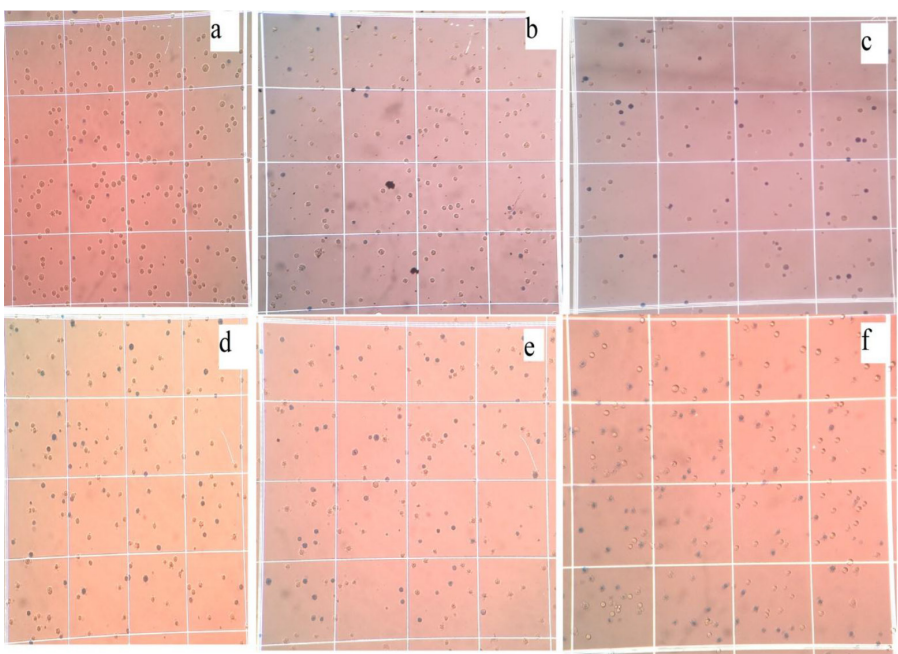

Figure 8: Anticancer activity of $\mathrm{Ag}_{2} \mathrm{O}$ nanoparticles a) Control b) $10 \mathrm{mg}$ c) $20 \mathrm{mg}$ d) $50 \mathrm{mg}$ e) $100 \mathrm{mg}$ f) $200 \mathrm{mg}$

Table 3: Anticancer activity results of $\mathbf{A g}_{2} \mathbf{O}$ nanoparticles.

\begin{tabular}{|c|c|c|c|c|c|c|c|c|}
\hline Cell & \multicolumn{2}{|c|}{ Name of sample } & \multicolumn{6}{|c|}{ Anticancer Results } \\
\hline \multirow[t]{2}{*}{ DLA } & $\begin{array}{l}\mathrm{Ag}_{2} \mathrm{O} \\
\text { nano- }\end{array}$ & $\begin{array}{c}\text { Concentration } \\
\mu \mathrm{g} / \mathrm{ml}\end{array}$ & Control & 10 & 20 & 50 & 100 & 200 \\
\hline & particles & $\%$ of inhibition & 100 & 12 & 26 & 30 & 42 & 56 \\
\hline
\end{tabular}

\section{DISCUSSION}

The scheme of the possible mechanism for the formation of silver oxide nanoparticles is given in Figure 1. Suresh et al. performed Preliminary phytochemical screening for the ethanolic extract of C. nilgiriensis and confirmed the presence of Tannin, Saponnin, Flavonoids, Steroids, Terpenoids, Triterpenoids, Carbohydrate, Protein, Anthroquinone, Polyphenol, Glycoside and Coumarin. ${ }^{25}$ Flavonoids are a group of polyphenolic compounds comprising anthocyanins, isoflavonoids, flavonols, chalcones, flavones and flavanones. The metal ion reduction may be due to the internal mechanism which leads to the conversion ketone to carboxylic acid in flavonoids. Some flavonoids have the ability to chelate with metal ion with their carbonyl group or p-electrons. Moreover, the functional group of water-soluble compounds such as flavonoids, terpenoids and phenolic groups present in the aqueous extracts of $C$. nilgiriensis appears to be responsible for the synthesis of $\mathrm{Ag}_{2} \mathrm{O}$ nanoparticles and their stabilization. Johnson et al. ${ }^{26}$ reported the reduction of $\mathrm{Ag}$ ions and the stabilization of $\mathrm{Ag}$ nanoparticles due to the presence of flavonoids in Cyathea nilgiriensis extracts. In this work the flavonoid type of compounds could have formed complex with silver (I) ion of Silver Nitrate solution. Then this complex solution was then heated in hot air oven for $8 \mathrm{hr}$ to form silver hydroxide further it was calcinated at $600^{\circ} \mathrm{C}$ to form stable silver oxide nanoparticles.

The results of FTIR analysis confirmed that phenolic compounds in flavonoids have a stronger ability to bind with metal, indicating that phenolic group could form metal nanoparticles to prevent agglomeration and thereby stabilize the medium. This suggests that biological molecules could do dual functions of formation and stabilization of silver oxide nanoparticles in aqueous medium.

From the antibacterial report it's clear that the inhibition created of biosynthesized $\mathrm{Ag}_{2} \mathrm{O}$ nanoparticles is due to disruption of the membrane with the generation of surface oxygen species, which play an important 
role and finally lead to the death of pathogens. Interestingly, the inhibition zone was different according to the type of pathogens and the concentrations of $\mathrm{Ag}_{2} \mathrm{O}$ nanoparticles employed. From the antimicrobial result its clear that by increasing the concentration of $\mathrm{Ag}_{2} \mathrm{O}$ nanoparticles in the discs, the growth inhibition has also been increased consistently because of proper diffusion of nanoparticles in the agar medium. Another impact is due to the small size of nanoparticle than the pore size of bacteria it crosses the cell membrane of the bacteria and inhibits its growth ${ }^{27}$

The antifungal activity of $\mathrm{Ag}_{2} \mathrm{O}$ is probably derived, through the electrostatic attraction between negatively charged cell membrane of microorganism and positively charged nanoparticles and the orientation of $\mathrm{Ag}_{2} \mathrm{O}$ nanoparticles. ${ }^{28} \mathrm{Ag}_{2} \mathrm{O}$ nanoparticles synthesized using green method was found to have good antifungal activity against the tested fungi. Thus, nanoparticles can be used as potential antifungal agents and help overcome the hurdles in fungal disease management posed by development of resistance to conventional fungicides.

From the Anticancer activity report it's clear that the increase of concentration from $10 \mu \mathrm{g}$ to $200 \mu \mathrm{g}$ increases the inhibition. At $200 \mu \mathrm{g}$ the maximum percentage of inhibition was observed for $\mathrm{Ag}_{2} \mathrm{O}$ nanoparticles. So it is concluded that green synthesized silver oxide nanoparticles have shown good antimicrobial and anticancer behavior at different concentrations.

\section{CONCLUSION}

$\mathrm{Ag}_{2} \mathrm{O}$ nanoparticles have been successfully synthesized via novel greener procedure using only silver nitrate and the aqueous extract of the leaves of Cyathea nilgiriensis Holttum. The biosynthesis of $\mathrm{Ag}_{2} \mathrm{O}$ nanoparticles was done via hydroxide precipitation followed by calcination at $600^{\circ} \mathrm{C}$. The $\mathrm{Ag}_{2}$ Onanoparticles were analyzed through PSA, XRD, FT-IR, SEM and EDX to prove the characteristics of the nanoparticles. The PSA result confirmed the produced $\mathrm{Ag}_{2} \mathrm{O}$ nanoparticles are below $100 \mathrm{~nm}$ in size. Biosynthesized $\mathrm{Ag}_{2} \mathrm{O}$ nanoparticles were found to have significant antimicrobial and anticancer activities. The $\mathrm{Ag}_{2} \mathrm{O}$ nanoparticle can be studied further to be the composite of a drug for commercial biomedical applications.

\section{ACKNOWLEDGEMENT}

The authors are extremely grateful to the SNS College of technology, Coimbatore, Tamil Nadu, India for providing financial support (faculty research seed money) and research facilities to accomplish this study.

\section{CONFLICT OF INTEREST}

There is no conflict of interest with this research.

\section{ABBREVIATIONS}

PSA: Particle Size Analyzer; XRD: X-ray Diffraction Analysis; FT-IR: Fourier Transform Infrared Spectroscopy; SEM: Scanning Electron Microscope; EDX: Energy Dispersive X-Ray; S. aureus: Staphylococcus aureus; B. subtilis: Bacillus subtilis; M. luteus: Micrococcus luteus; $E$. coli: Escherichia coli; S. paratyphi: Salmonella paratyphi; K. pneumonia: Klebsiella pneumoniae; C. albicans: Candida albicans; A. niger: Aspergillus niger.

\section{REFERENCES}

1. Velmurugan $P$, Sivakumar $S$, Song YC, Jang SH. Crystallization of silver metal by extract of Prunus yedoensis Matsumura blossoms and its potential character ization. J Ind Eng Chem. 2015;31:39-42.

2. Palanisamy S, Rajasekar P, Vijayaprasath G, Ravi G, Manikandan R, Prabhu NM. A green route to synthesis silver nanoparticles using Sargassum polycystum and its antioxidant and cytotoxic effects: An in vitro analysis. Mater Lett. 2017;189:196-200.

3. Velmurugan P, Shim J, Bang KS, Oh BT. Gold nanoparticles mediated coloring of fabrics and leather for antibacterial activity. J Photochem Photobiol B. 2016;160:102-9

4. Dong $C$, Cao $C$, Zhang $X$, Zhan $Y$, Wang $X$, Yang $X$, et al. Wolfberry fruit (Lycium barbarum) extract mediated novel route for the green synthesis of silver nanoparticles. Optik. 2017;130:162-70

5. Derikvand F, Bigi F, Maggi R, Piscopo CG, Sartori G. Oxidation of hydroquinones to benzoquinones with hydrogen peroxide using catalytic amount of silver oxide under batch and continuous-flow conditions. J Catal. 2010;271(1): 99-103.

6. Wang W, Zhao Q, Dong J, Li J. A novel silver oxides oxygen evolving catalyst for water splitting. Int J Hydrog Energy. 2011;36(13):7374-80.

7. Petrov VV, Nazarova TN, Korolev AN, Kopilova NF. Thin sol-gel $\mathrm{SiO}_{2}-\mathrm{SnO}_{-}-\mathrm{AgO}$ films for low temperature ammonia gas sensor. Sens: Actuators B Chem. 2008;133(1):291-5.

8. Sanli E, Uysal BZ, Aksu ML. The oxidation of $\mathrm{NaBH}_{4}$ on electrochemicaly treated silver electrodes. Int J Hydrog Energy. 2008; 33(8):2097-104.

9. Ida Y, Watase $S$, Shinagawa T, Watanabe M, Chigane M, Inaba M, et al. Direct electrode position of $1.46 \mathrm{eV}$ bandgap silver (I) oxide semiconductor films by electro generated acid. Chem Mater. 2008;20(4):1254-6.

10. Wei $X L$, Catherine $S$, Matthias $S$. Insights into the function of silver as an oxidation catalyst by ab initio atomistic thermodynamics. Phys Rev B. 2003;68(16):165412-15.

11. Yuan HW, Hai YG. Hemoglobin co-immobilized with silver-silver oxide nanoparticles on a bare silver electrode for hydrogen peroxide electro analysis. Microchim Acta. 2009;164(1-2):41-7

12. Antony $\mathrm{E}$, Sathiavelu $\mathrm{M}$, Arunachalam S. Synthesis of $\mathrm{Ag}_{2} \mathrm{O}$ NPs from the medicinal plant Bauhinia acuminata and Biophytum sensitivum: A comparative study of its biological Activities with plant extract. Int J Appl Pharm. 2017; 1:22-9.

13. Joshi R, Kaushik U, Upadhyaya A, Sharma P. Green technology mediated synthesis of $\mathrm{Ag}_{2} \mathrm{O}$ NPs from Momordica charantia fruit extract and its bactericidal activity. Asian J Pharm Clin Res. 2017; 10(3):196-200.

14. Irian S. Green synthesis of metal nanoparticles using plants. Green Chem. 2011;13:2638-50

15. Geethalakshmi R, Sarada LVD. Synthesis of plant-mediated silver nanoparticles using Trianthema decandra extract and evolution of their antimicrobial activities. Int J Eng Sci Technol. 2010;2(5):970-5.

16. Bauer AW, Kirby WM, Scherris JC, Truck M. Antibiotic susceptibility testing by a standardized single disc method. Am J Clin Pathol. 1996;45(4):493-6.

17. Gupta SK. Handbook of practical and Clinical Immunology. $3^{\text {rd }}$ Edition. New Delhi, India: CBS Publishers and Distributors. 2002;299-300.

18. Rajkapoor B, Jayakar B, Murugesh N. Antitumor activity of Bauhinia variegataon Dalton's Ascitic lymphom. J Ethnopharmacol. 2003;89(1):107-9.

19. Loría BM, Herrera KW, Cauich RJ, Cervantes UJ, Vázquez TH, Ávila OA. FTIR study on the thermal degradation of poly (vinyl pyrrolidone). J Therm Anal Calorim. 2010;104(2):737-42

20. Giri N, Natarajan R, Gunasekaran S, Shreemathi S. ${ }^{13} \mathrm{C}$ NMR and FTIR spectroscopic study of blend behavior of PVP and nano silver particles. Arch Appl Sci Res. 2011; 3(5):624-30.

21. Yong NL, Ahmad A, Mohammad AW. Synthesis and characterization of silver oxide nanoparticles by a novel method. Int J Sci Eng Res. 2013;4:155-8.

22. Janardhanan R, Karuppaiah M, Hebalkar N, Rao TN. Synthesis and surface chemistry of nano silver particles. Polyhedron. 2009;28(12):2522-30.

23. Wei W, Mao X, Luis AO, Sadoway DR. Oriented silver oxide nanostructures synthesized through a template free electrochemical route. Journal of materials chemistry. J Mater Chem. 2010;21(2):432-8.

24. Greulich C, Diendorf J, Simon T, Eggeler G, Epple M. Uptake and intracellular distribution of silver nanoparticles in human mesenchymal stem cells. Acta Biomater. 2011;7(1):347-54.

25. Suresh J Pradheesh G, Alexramani V Hong SI. Phytochemical Screening Characterization and Antimicrobial, Anticancer Activity of Biosynthesized Zinc Oxide Nanoparticles Using Cyathea nilgiriensis Holttum Plant Extract. J Bionanosci. 2018;12(1):37-48.

26. Johnson MA Santhanam A, Thangaiaha S, Narayanan J. Green synthesis of silver nanoparticles using Cyathea nilgirensis Holttum and their cytotoxic and phytotoxic potentials. Parti Sci Tech. 2017; 1-5.

27. Sunita J, Suresh G, Madhav N, Anjali R, Copper Oxide Nanoparticles, Synthesis, characterization and their antibacterial activity. J of Clus Sci. 2011;22(2):121-9.

28. Dragieva I, Stoeva S, Stoimenov P, Pavlikianov E, Klabunde K. Complex formation in solutions for chemical synthesis of nanoscaled particles prepared by borohydride reduction process. Nanostruc Mater. 1999;12(1-4):267-70.

Article History: Submission Date : 27-03-2020; Revised Date : 16-04-2020; Acceptance Date : 09-05-2020.

Cite this article: Pradheesh G, Suresh S, Suresh J, Alexramani V. Antimicrobial and Anticancer Activity Studies on Green Synthesized Silver Oxide Nanoparticles from the medicinal plant Cyathea nilgiriensis Holttum. Int. J. Pharm. Investigation. 2020;10(2):146-50. 